\title{
With a little help from our friends: The effect of USAID assistance on SME growth in a transition economy
}

\author{
El-hadj Bah ${ }^{\mathrm{a}}$, Josef C. Brada ${ }^{\mathrm{b}, \mathrm{c}, *}$, Taner Yigit ${ }^{\mathrm{d}}$ \\ a The University of Auckland, Private Bag 92019, Auckland 1142, New Zealand \\ ${ }^{\mathrm{b}}$ Arizona State University, PO Box 879801, Tempe, AZ 85287-9801, USA \\ ${ }^{\mathrm{c}}$ Macedonian Academy of Sciences and Arts, Bul. Krste Misirkov, 2, 1000 Skopje, Republic of Macedonia \\ ${ }^{\mathrm{d}}$ FEASS, Bilkent University, Ankara 06800, Turkey
}

\section{A R T I C L E I N F O}

\section{Article history:}

Received 17 March 2010

Revised 28 February 2011

Available online 16 March 2011

\section{JEL classification:}

D21

H25

$\mathrm{H} 43$

$\mathrm{H} 81$

P23

\section{Keywords:}

Job creation

Assistance to firms

Small and medium-sized enterprises

Foreign aid

Program evaluation

\begin{abstract}
A B S T R A C T
Bah, El-hadj, Brada, Josef $\mathbf{C}$., and Yigit, Taner-With a little help from our friends: The effect of USAID assistance on SME growth in a transition economy

Using survey data on Macedonian firms that participated in USAID programs providing technical and financial assistance for small and medium-sized enterprises (SMEs) and on firms that did not, we estimate the effectiveness of such assistance in increasing the growth of employment in the assisted firms. We control for selection bias in program participation and use both kernel and caliper propensity score matching to estimate the excess growth of employment in assisted firms. We find that assistance programs raised employment growth by $16-20$ percentage points in the first year after assistance and by 26-30 points by the third year. Journal of Comparative Economics xxx (xx) (2011) xxx-xxx. The University of Auckland, Private Bag 92019, Auckland 1142, New Zealand; Arizona State University, PO Box 879801, Tempe, AZ 85287-9801, USA; Macedonian Academy of Sciences and Arts, Bul. Krste Misirkov, 2, 1000 Skopje, Republic of Macedonia; FEASS, Bilkent University, Ankara 06800, Turkey.
\end{abstract}

(c) 2011 Association for Comparative Economic Studies Published by Elsevier Inc. All rights reserved.

\section{Introduction}

One of the more troubling aspects of the economic transition in Eastern Europe has been that the growth of aggregate output since the early to mid-1990s has been accompanied by stagnant or declining employment, particularly in South East Europe. This has resulted in gains in wages, clearly a desirable result, but in some countries it has also resulted in high levels of unemployment or underemployment, creating a phenomenon that some observers have called "jobless growth". ${ }^{1}$ The lack of job growth, particularly in the SEE countries has contributed to a variety of social and political problems, and dealing with them has been a serious policy concern, both in the countries of the region and among foreign assistance donors. One of, if not the, worst performing transition countries in terms of unemployment has been the Republic of Macedonia, whose registered unemployment rate over the past 20 year period peaked above $40 \%$ and remains in the low- to mid-30 percent rate to this

\footnotetext{
* Corresponding author at: Arizona State University, PO Box 879801, Tempe, AZ 85287-9801, USA. Fax: +1 4809656524.

E-mail address: josef.brada@asu.edu (J.C. Brada).

${ }^{1}$ For a discussion of this phenomenon and related labor market issues see, Svejnar (2002a,b). Brown and Earle (2008) examine this phenomenon from the standpoint of firm-level data.
} 
day. ${ }^{2}$ Lehmann (2010) describes Macedonia as "one of the worst performing economies in Europe, both in terms of unemployment and employment rates" in large part due to the fact that it "shows very little capacity of job creation" (p. 6).

Given Macedonia's poor labor market performance, foreign aid donors have focused much of their assistance to the country on job creation programs. Moreover, given the lack of small and medium-sized enterprises (SMEs) at the start of transition and the widely-held perception that SMEs have the potential to create jobs rapidly and in large numbers, much of that assistance has been directed at SMEs. In this paper we examine the effectiveness of a set of programs developed by the United States Agency for International Development (USAID) to provide mainly technical assistance, but also financial assistance, to Macedonian firms in order to improve their performance and particularly to increase the number of jobs that they provide. The technical assistance programs provided business and technical knowledge and skills to Macedonian entrepreneurs through training, seminars, demonstrations and consulting. We employ survey data collected from Macedonian firms that had participated in USAID program as well as from firms that had not, and we estimate the effects of USAID assistance on job creation in recipient firms using matching techniques that compare their performance to a sample of firms that did not receive assistance. We find that USAID assistance had a positive and significant effect, in both the statistical and in the economic senses, on full-time and total employment in Macedonian firms that participated in USAID programs.

In the next section of the paper we selectively review the literature on the effectiveness of technical and financial assistance to firms in market economies as well as the more limited literature on the effectiveness of assistance to firms in transition economies. Section 3 describes the data used in this study as well as the surveys used to obtain the data. Section 4 explains the matching techniques we use to estimate the effectiveness of USAID programs in Macedonia, and Section 5 presents the results of our estimates of job creation due to the assistance that firms received, compares them with other relevant studies and draws out the policy implications. Section 6 concludes and suggests avenues for further research.

\section{Barriers to firm growth}

Research on the barriers to the growth of SMEs in transition economies was initially directed toward identifying the most important changes in the business and regulatory environment of transition economies so as to promote SME formation, survival and growth. Johnson et al. (2000) studied firms in five transition economies and concluded that the main barrier to SME growth lay much more in unclear property rights than in lack of access to bank credit. Pissarides et al. (2003), on the other hand, concluded, based on their analysis of Bulgarian and Russian managers' perceptions, that lack of finance was a much greater barrier than were unclear property rights. While such studies may have been useful in guiding policy makers in these countries in shaping their reform agendas, they do have a number of shortcomings as guides to formulating programs to assist SMEs in the region now. In part this is due to the fact that the data from which these conclusions are drawn are now rather dated, with the former study based on 1994-1996 data and the latter on surveys administered in 1995. Clearly, there has been tremendous, although varying by country, progress in both the development of the financial sector and in the strengthening of property rights and the rule of law in many transition countries, and thus the barriers that were important in the early stages of the transition are not necessarily the ones that need to be addressed now. Moreover, these studies did not attempt any evaluation of the effectiveness of assistance to SMEs in overcoming the obstacles to growth, and thus they are of limited use in framing current and future assistance programs. Finally, Commander and Svejnar (in press) show that the effect of these and other perceived barriers to growth is hard to demonstrate when the barriers are introduced jointly or when country fixed effects are accounted for.

More relevant for the evaluation and design of assistance programs for SMEs in transition economies are two studies, Brown et al. (2005) and Brown and Earle (2009), that examine the effectiveness of financial assistance programs for Romanian SMEs. The first of these is a study that, like ours, is based in part on a survey of firms, but it includes only firms that participated in assistance programs, imposing a significant econometric burden to account for the "counterfactual" of the performance of firms that did not participate in such programs. Besides being more recent than the previously mentioned studies because their surveys were undertaken in 2000, Brown et al. (2005) were able to cover a longer time period from the time of the firm's founding to the time of the survey. In a follow-up paper, Brown and Earle (2009) added Romanian firms that did not participate in the assistance programs to their sample, and thus they were able to use matching methods to better estimate the effects of assistance. Both papers conclude that financial assistance did have a positive and significant impact on firm growth, but technical assistance, although valued by recipients, had no significant effect on job creation in the recipient firms. ${ }^{3}$

While the evidence from transition economies of the effectiveness of assistance to SME's is thus limited to this paper and the two studies just discussed, there is large body of research on the effectiveness of both financial and technical assistance to SMEs in market economies, and we briefly and selectively review this literature to put our findings and methodology into a broader perspective. We begin by noting that many countries and regional governments fund and operate assistance

\footnotetext{
2 The high registered unemployment rate is partly due to the linking of health benefits to an individual's status as either working or registered unemployed. Labor force survey data report unemployment rates that are on average about 10 percentage points lower, still a high level by international standards.

3 The authors report some positive effects of technical assistance in some of their regression results, but not in the majority of their specifications and not in those estimates that appear most reliable from an econometric standpoint.
} 
programs for SMEs. In part this is based on the widely-held belief that SMEs are particularly effective at promoting growth of both output and employment. ${ }^{4}$

A second reason for the existence of programs to assist SMEs is that proponents of such programs contend that SME's are burdened by market and information failures to a greater degree than are large firms. For example, programs to provide subsidized loans to SMEs or to help them apply for commercial credit can be found in many countries. The rationale for such programs includes high interest rates charged to SMEs by financial institutions, in part due to poorer financial and business information that SMEs are able to provide; higher risk premia for SMEs; the reluctance of financial institutions to cover the administrative costs of small loans; the lack of longer-term credits to SMEs, etc. Studies demonstrating the effectiveness of loan supports in improving SME formation, employment growth and/or firm survival can be found, for example, for programs implemented in the US (Brash and Gallagher, 2008), Germany (Almus, 2001), New Zealand (Ministry of Economic Development of New Zealand, 2009), and Northern Ireland and the Republic of Ireland (Hart and Gudgin, 1999; Roper and Hewitt-Dundas, 2001). There are, as well, studies that fail to find evidence of the benefits of financial assistance for SMEs, for example in Mexico (World Bank, 2007). The conflicting evidence on the effectiveness or lack thereof of these programs may reflect the conceptual difficulties of separating the effect of assistance from other factors that influence firm performance or cross-country differences in the effectiveness of these programs due to the way in which they are designed, administered and funded.

Many countries and regional governments also provide technical assistance to SMEs for much the same reasons they provide financial assistance: to support SME growth and to overcome market imperfections. One such barrier to SME growth and survival that many programs attempt to address is lack of managerial, business and technical expertise. That the lack of such expertise is an important barrier to SME success is demonstrated by Westhead (1995), who allocated a sample of UK firms into four clusters, one characterized as having founders who were "managerially sophisticated", two with founders characterized as being "technologically qualified", and one having inexperienced founders with limited technological networks. Although his sample size precluded strong statistical inferences, the documented performance of firms in the four clusters clearly suggests that, as one would expect, lack of managerial skills combined with a lack of access to technological networks was a major barrier to the success of SMEs.

It is to be expected that entrepreneurs in transition economies are likely to be lacking in business and technical skills to a greater degree than are their market-economy counterparts. Moreover, managers of SMEs who lack such managerial and technological skills are unlikely to purchase them from outside sources because they fail to understand the potential benefits of doing so, because they are reluctant to share control and information with outsiders, and because day-to-day issues of running the business limit the time available for formulating growth strategies and acquiring new business and technical skills (Ministry of Economic Development of New Zealand, 2009; Chrisman and McMullan, 2004). In transition economies, such consultancy services are also likely to be both underappreciated and in short supply.

SMEs also tend to underinvest in R\&D, and the resulting lack of technical capabilities hampers their ability to adopt new process technology and thus to grow. Lerner (1999) provides evidence that support for improvements in SMEs' technological capabilities improves the performance of US MNCs, and Meriküll (2010) finds similar evidence for Estonian firms. In contrast to Brown and Earle's (2009) finding of ineffectiveness of non-financial assistance to Romanian SMEs, the Ministry of Economic Development of New Zealand (2009) finds that programs to provide consultancy and business skills to New Zealand SMEs are effective in improving their growth and survival, as do Wren and Storey (2002) for UK SMEs. A finding that technical assistance does improve firm performance has important policy significance because technical advice provided through seminars, training sessions and instructional materials is more in the nature of a public good in that more firms can receive this kind of assistance at low or zero marginal cost, while the reach of financial assistance is constrained to the funds allocated for the program.

Based on the foregoing evidence, firms in developed market economies seem to benefit from programs that provide financial and technical assistance. Whether firms in Macedonia can benefit from similar programs depends in part on whether such programs address the obstacles to growth that they face by virtue of their transition-economy environment. In the survey of Macedonian mangers that we conducted and that we describe below, we asked respondents to rate the importance of a number of factors considered likely barriers to firm growth in transition economies. Managers were asked to rank these on a scale of zero, meaning not a barrier to growth to two, meaning a serious barrier to growth. Results are reported in Table 1.

Quite clearly Macedonia's status as a transition economy seems to pose formidable barriers to the survival and growth of firms. The first four items in Table 1 relate to the government's ability to enforce the rule of law and provide secure property rights. Competition from the black market and from unregistered firms, which have a competitive advantage because they avoid paying taxes and conforming to safety, phytosanitary and labor regulations, is by far the most serious barrier to their firm's growth reported by Macedonian mangers. Legal disputes, mainly having to do with disputes over the ownership of firms, and high taxes are also seen as important barriers to growth.

The other items in Table 1 have to do with the availability of inputs. Obtaining a business premises and purchasing needed material inputs on the market are not major barriers to firms' growth. The supply of labor also does not appear to be a problem for firms, a finding consistent with the high rate of unemployment. However about one-third of the firms do report that the lack of skilled managers is a serious barrier to their growth, and 19\% report it to be a moderate barrier.

\footnotetext{
${ }^{4}$ For a discussion of the evidence that SME's contribute to employment growth in transition economies, see Brown and Earle (2008).
} 
Table 1

Barriers to firm growth as reported by Macedonian managers.

\begin{tabular}{|c|c|c|}
\hline Barrier to growth & & (\% of total observations) \\
\hline Competition from black market and unregistered firms & $\begin{array}{l}0 \text { (not a barrier) } \\
1 \text { (moderate barrier) } \\
2 \text { (serious barrier) }\end{array}$ & $\begin{array}{l}20.5 \\
15.0 \\
62.0\end{array}$ \\
\hline Legal disputes & $\begin{array}{l}0 \text { (not a barrier) } \\
1 \text { (moderate barrier) } \\
2 \text { (serious barrier) }\end{array}$ & $\begin{array}{l}38.5 \\
21.1 \\
36.2\end{array}$ \\
\hline $\begin{array}{l}\text { Business } \\
\text { Environment and regulations }\end{array}$ & $\begin{array}{l}0 \text { (not a barrier) } \\
1 \text { (moderate barrier) } \\
2 \text { (serious barrier) }\end{array}$ & $\begin{array}{l}42.7 \\
30.9 \\
25.2\end{array}$ \\
\hline Taxes & $\begin{array}{l}0 \text { (not a barrier) } \\
1 \text { (moderate barrier) } \\
2 \text { (serious barrier) }\end{array}$ & $\begin{array}{l}32.5 \\
27.1 \\
38.5\end{array}$ \\
\hline Acquiring a business premises & $\begin{array}{l}0 \text { (not a barrier) } \\
1 \text { (moderate barrier) } \\
2 \text { (serious barrier) }\end{array}$ & $\begin{array}{l}56.1 \\
23.6 \\
19.2\end{array}$ \\
\hline Access to external finance & $\begin{array}{l}0 \text { (not a barrier) } \\
1 \text { (moderate barrier) } \\
2 \text { (serious barrier) }\end{array}$ & $\begin{array}{l}32.6 \\
22.0 \\
43.6\end{array}$ \\
\hline Availability of inputs on the market & $\begin{array}{l}0 \text { (not a barrier) } \\
1 \text { (moderate barrier) } \\
2 \text { (serious barrier) }\end{array}$ & $\begin{array}{l}50.9 \\
29.7 \\
18.5\end{array}$ \\
\hline Availability of internal finance & $\begin{array}{l}0 \text { (not a barrier) } \\
1 \text { (moderate barrier) } \\
2 \text { (serious barrier) }\end{array}$ & $\begin{array}{l}35.8 \\
25.6 \\
36.5\end{array}$ \\
\hline Availability of appropriate labor & $\begin{array}{l}0 \text { (not a barrier) } \\
1 \text { (moderate barrier) } \\
2 \text { (serious barrier) }\end{array}$ & $\begin{array}{l}46.0 \\
25.0 \\
27.6\end{array}$ \\
\hline Availability of managers with needed skills & $\begin{array}{l}0 \text { (not a barrier) } \\
1 \text { (moderate barrier) } \\
2 \text { (serious barrier) }\end{array}$ & $\begin{array}{l}42.5 \\
19.0 \\
31.6\end{array}$ \\
\hline
\end{tabular}

Notes: This table reports the frequencies for responses of $0,1,2$. The total may not add to $100 \%$ due to missing responses. Because we have panel data, an observation is a firm's response for each year for which the firm evaluated barriers to growth. Thus firms may have responded for several years, and their responses may have differed from 1 year to the next.

Thus, technical assistance programs that develop managers' business and technical skills should be of help to Macedonian firms. About $44 \%$ of managers report that lack of access to external finance is a serious barrier to their firm's growth and another $22 \%$ rate is as a moderate barrier. The lack of internally generated funds for expansion is also rated as an important barrier by over one-third of the firms. These responses suggest that Macedonian firms' growth does appear to be constrained by a lack of financing, and programs designed to improve their access to credit, either by providing financial support or through programs that improve managers' skills in applying for loans, should have a positive effect on their growth as well. Thus it is reasonable to expect that programs that provide business and technical skills to SME managers in Macedonia, as well as programs that improved their access to external finance, if well-conceived and effectively delivered, should have some positive impact on SMEs' job creation.

\section{Data}

\subsection{Firm-level surveys}

In an ideal environment, the effectiveness of a policy intervention at the firm level could be estimated using a random sample of firms, with information covering periods before, after, and during the phase of policy intervention. If participation in the program is not random, then steps must be taken to account for the possibility of selection bias. Such selection bias can arise if firms are chosen by program organizers in a way that favors participation by firms more likely to benefit from the program or that have good growth prospects relative to other firms because of firm-specific characteristics. Alternatively, firms with better growth prospects may self-select to participate in the program. ${ }^{5}$ If a random sample of firms is not available, then there should some effort to match the firms receiving assistance and those not receiving assistance in terms of major

\footnotetext{
${ }^{5}$ In the case of assistance programs for SMEs, such selection bias is desirable in that scarce program resources should be directed toward firms that have the greatest potential to make effective use of them. Roper and Hewitt-Dundas (2001), for example, criticize some of the assistance programs they evaluate for their inability to discriminate between firms that are likely to benefit from assistance and those that are not.
} 
firm characteristics such as size, industry and location, or the differences between the two groups of firms should be controlled for in the specification of the model. Unfortunately, there was no systematic collection of data on the performance of Macedonian firms either before or after they participated in USAID programs, and this data, as well as data on the performance of firms that did not participate in USAID programs had to be obtained ex post through field surveys. ${ }^{6}$

The survey consisted of a questionnaire administered in face-to-face interviews of about $1 \mathrm{~h}$ with firm mangers, conducted in Macedonian. ${ }^{7}$ The survey asked for a count of employees rather than the firm's wage bill because it was deemed unlikely that a sufficiently large number of respondents would be able to recall the history of their wage bill in sufficient detail, and that requiring wage-bill information would introduce a bias toward larger and more successful firms. We did, however, seek to obtain information on both full-time and part-time employment in order to investigate whether there was a differential effect of assistance on employment growth or whether part-time employees were cannibalizing the jobs of full-time workers. ${ }^{8}$ Also on the survey were questions about firm characteristics and the respondents' subjective perceptions of barriers to the growth of their firm. Respondents also indicated whether they had participated in programs to provide technical or financial assistance from USAID and other programs and the year(s) in which such support had been received.

The survey was administered by a Macedonian market research firm. The objective was to obtain a sample of 100 firms that had participated in USAID assistance programs and a control group of 100 firms not known to have received assistance, matched for location and, where possible, for business sector. We identified potential respondent firms that had received USAID assistance by reviewing publicly available sources of information on USAID activities, by obtaining names directly from the USAID office in Macedonia and from the USAID contractors and implementers who had run assistance projects in Macedonia. We also used information from USAID's TraiNet database. Because some of our contact data were over a decade old, we identified about 400 firms that may have received USAID assistance. Ideally, this sample would have mirrored the mix of USAID funding for the two main types of assistance programs sponsored by USAID: technical assistance to firms and financial assistance. In fact, the number of recipients of financial assistance we were able to obtain from contractors and implementers fell short of this as we detail below. Thus, we included in our potential sample every recipient of financial assistance we were able to identify and then sampled randomly from the remaining list of 400 firms until 100 firms had been surveyed. This yielded a list of 14 firms that had received financial assistance and 86 that had received technical assistance. The Macedonian survey firm, upon receiving the list of $400 \mathrm{firms}$, analyzed it by sector and geographic region and produced a sample of companies not known to have received USAID assistance with a similar sectoral and regional distribution as our assisted sample, thus to some extent controlling for location and sector effects. The survey was administered from July to August 2007. Among the firms on our list that could be located, the response rate was $70 \%$.

\subsection{Descriptive statistics}

Our data set is an unbalanced panel. The estimation method used in this paper exploits the panel dimension to decrease the effect of selection bias on our estimates of program effectiveness. While our initial survey covered 200 firms for the period 1992-2007, the final number of treated firms used in the estimation is smaller. First, of the 100 treated firms surveyed, 10 did not recall receiving USAID assistance. ${ }^{9}$ The remaining 90 treated firms were further reduced in number by eliminating five firms that failed to identify assistance dates; three firms that gave inconsistent dates for USAID assistance (aid reported in a year before the firm was founded); two firms that were founded in 2007, which means that there was no data with which to calculate post-assistance employment growth; and eight firms that received assistance in the year they were formed, which prevents us from calculating employment growth in the assistance year. We also dropped three firms that had received USAID assistance prior to 1996 because the early 1990s were characterized by chaotic economic conditions and extensive firm restructuring.

Of the 69 remaining treated firms, a further 11 had to be dropped from the sample because of incomplete data, leaving a total of 58 treated firms for estimation purposes. ${ }^{10}$ Thirty-four firms received only technical assistance, three firms received only financial assistance, and the remainder received both types of assistance. Of the firms receiving both types of assistance, ten received technical assistance before receiving financial assistance, five received financial assistance first, and six received financial and technical assistance in the same year. If a firm received USAID assistance in year $t$ and then USAID or other government assistance again in a subsequent year, say, $t+n$, we only estimated the treatment effect for the first instance of

\footnotetext{
${ }^{6}$ A shortcoming of such a retrospective approach is that firms that have not survived until the time that the sampling took place cannot be included in the study thus overestimating the effectiveness of assistance. On the other hand, if USAID programs have some positive effect on firm survival rates, this effect cannot be measured, suggesting possible underestimation of overall program effectiveness. Some researchers take the inability to locate firms as evidence of firm failure; given the incomplete record keeping on assisted firms in Macedonia, this was not an option in this study.

${ }^{7}$ An English-language version of the survey is available from the authors upon request.

8 The lack of part-time job opportunities appears is an important barrier to the ability of new and young workers to gain labor market experience. Lehmann (2010) reports that part-time work is common only in agriculture in Macedonia.

${ }^{9}$ In part this was due to the fact that respondents tended to associate the assistance program in which they participated with the contractor running the program rather than with USAID, the sponsor. In some cases, if respondents were prompted with the name of the contractor, they did recall receiving assistance.

${ }^{10}$ Often this involved missing data on the pre-assistance year characteristics. We tested whether the firms with missing data differed from the 58 remaining firms. Aside from employment, the only other continuous variable is age. There is no significant employment or age difference between deleted and remaining firms. For the discrete variables, there is no significant difference between the two groups of firms either.
} 
Table 2

Distribution of observations by year.

\begin{tabular}{cccc}
\hline \multirow{2}{*}{ Year } & Firms receiving & & \\
\cline { 2 - 4 } & No assistance & USAID assistance & Total \\
\hline 1996 & 37 & 4 & 41 \\
1997 & 42 & 0 & 42 \\
1998 & 47 & 1 & 48 \\
1999 & 53 & 0 & 53 \\
2000 & 57 & 1 & 58 \\
2001 & 64 & 5 & 69 \\
2002 & 65 & 4 & 69 \\
2003 & 68 & 13 & 81 \\
2004 & 74 & 9 & 83 \\
2005 & 81 & 12 & 93 \\
2006 & 87 & 9 & 96 \\
2007 & 89 & 0 & 89 \\
Total & 764 & 58 & 822 \\
\hline
\end{tabular}

Notes: An assisted firm is counted only once in the assistance year but has employment data at least 2 , and up to 5 , years. Non-assisted firms can be counted more than once. In a given year, we count all non-assisted firms that existed in the prior year if they have employment data for at least 2 years.

assistance, and we categorize the firm as having received financial or technical assistance on the basis of the first type of assistance obtained. The reason for this is that if we were also to estimate the treatment effect for the second instance of assistance, whether financial or technical, the estimate of the effect of the second treatment could be biased upward to the extent that there are longer-term effects of the first treatment on employment growth that carry over to the years over which the effect of the second treatment is estimated. The six firms that received financial and technical assistance in the same year were not placed in either category, but they were retained in the sample, and we present some results on the complemantarity of financial and technical assistance based on the limited experience of these six firms below.

After these deletions, 822 observations remained. An observation is a combination of a firm and its annual data for a given year because we have panel data. For firms that received assistance, there is one observation, which contains information on the year before assistance, another observation for the year in which assistance is received and then observations for up to 3 years after the receipt of assistance. Firms that did not receive assistance may have more than one observation with information of at least 2 years and a maximum of 4 years. For example, if a non-assisted firm (i) is created in 2000, then we have observations $i$-year from 2001 to 2007. Each $i$-year observation has characteristics before and after that year. Table 2 shows the yearly distribution of firms that received assistance in a given year as well as of unassisted firms that were potential matches. Most USAID assistance was provided between 2001 and 2006.

Table 3

Descriptive statistics.

\begin{tabular}{|c|c|c|c|c|}
\hline \multirow[t]{2}{*}{ Variable } & \multicolumn{2}{|l|}{ Total } & \multirow{2}{*}{$\begin{array}{l}\text { Assisted } \\
\text { Mean }\end{array}$} & \multirow{2}{*}{$\begin{array}{l}\text { Not assisted } \\
\text { Mean }\end{array}$} \\
\hline & Obs. & Mean & & \\
\hline \multicolumn{5}{|l|}{ Panel A: Continuous variables } \\
\hline Full-time employment & 822 & $\begin{array}{l}13.27 \\
(45.20)\end{array}$ & $\begin{array}{l}47.00 \\
(129.30)\end{array}$ & $\begin{array}{l}10.71 \\
(29.26)\end{array}$ \\
\hline Total employment & 822 & $\begin{array}{l}13.41 \\
(45.21)\end{array}$ & $\begin{array}{l}47.91 \\
(129.22)\end{array}$ & $\begin{array}{l}10.80 \\
(29.24)\end{array}$ \\
\hline Age & 822 & $\begin{array}{l}8.98 \\
(8.30)\end{array}$ & $\begin{array}{l}9.69 \\
(10.55)\end{array}$ & $\begin{array}{l}8.92 \\
(8.11)\end{array}$ \\
\hline Change in total employment in year $t$ & 822 & $\begin{array}{l}0.04 \\
(0.27)\end{array}$ & $\begin{array}{l}0.07 \\
(0.29)\end{array}$ & $\begin{array}{l}0.03 \\
(0.27)\end{array}$ \\
\hline Change in total employment in year $t+1$ & 730 & $\begin{array}{l}0.07 \\
(0.41)\end{array}$ & $\begin{array}{l}0.17 \\
(0.78)\end{array}$ & $\begin{array}{l}0.06 \\
(0.36)\end{array}$ \\
\hline Change in total employment in year $t+2$ & 630 & $\begin{array}{l}0.10 \\
(0.50)\end{array}$ & $\begin{array}{l}0.25 \\
(0.93)\end{array}$ & $\begin{array}{l}0.09 \\
(0.45)\end{array}$ \\
\hline Change in total employment in year $t+3$ & 534 & $\begin{array}{l}0.14 \\
(0.53)\end{array}$ & $\begin{array}{l}0.35 \\
(0.71)\end{array}$ & $\begin{array}{l}0.12 \\
(0.52)\end{array}$ \\
\hline \multicolumn{5}{|l|}{ Panel B: Dichotomous $(0-1)$ variables } \\
\hline & Obs. & $\%$ of obs. value $=1$ & $\%$ of obs. value $=1$ & $\%$ of obs. value $=1$ \\
\hline Sector $=$ industry & 822 & 6.00 & 3.45 & 6.15 \\
\hline Sector $=$ services & 822 & 49.27 & 39.66 & 50.00 \\
\hline At least one employee has a university degree & 822 & 57.54 & 77.59 & 56.02 \\
\hline Owner has a university degree & 822 & 67.60 & 82.46 & 66.49 \\
\hline Exports $>50 \%$ output & 822 & 21.65 & 34.48 & 20.68 \\
\hline
\end{tabular}


Table 3 reports the descriptive statistics for our sample. In Panel A of Table 3 we show the summary statistics for the continuous variables. We report both full-time and total employment, although the difference is quite small, reflecting the lack of part-time jobs in Macedonia. The average firm in the sample has 13 employees with a large standard deviation of 45 . The majority of the firms, $77.6 \%$, were small with less than 10 employees, $19 \%$ were medium-sized with between 10 and 50 employees and only $3.4 \%$ had more than 50 employees, the largest having 800 employees. As is to be expected, the age distribution is skewed toward young firms with $51 \%$ being less than 8 years old. The average age is 9 years with a standard deviation of 8.3 years. ${ }^{11}$ We also report the average total employment growth for the assistance year and for 1-3 years after the assistance year. Employment grows over time for assisted and unassisted firms, but the former exhibit higher rates of growth.

Panel B reports the summary statistics for discrete variables. Firms classified in the services sector represent almost 50\% of all observations, and manufacturing firms account for only $6 \%{ }^{12}$ Most firms' managers, $67.6 \%$, have a higher education and $57.5 \%$ of firms report employees who also have a higher education. Firms that export more than $50 \%$ of their production account for $21.7 \%$ of the sample. ${ }^{13}$

Table 3 also shows the differences between firms that received assistance and those that did not. The average employment in USAID assistance recipients is more than four times that of firms in the control group, although this is due to the presence of two large firms in the assisted group. ${ }^{14}$ The age difference between assisted and unassisted firms is less than 1 year, but the employment growth rates show large differences for all periods after assistance and the corresponding years in unassisted firms. There are also differences between assisted and unassisted firms in terms of the discrete variables; the former have better-educated managers and workers and more of them tend to export a large share of their output. While $3.45 \%$ of firms that received assistance are in industry, the corresponding share is $6.15 \%$ for the control group, which also has a higher share of firms in agriculture and agro-industry. For the propensity score estimation described below, we include the above variables and the variables related to firms' responses about the barriers to growth described in Table 1 . Because the variable related to taxes as a barrier to growth had many missing observations, we did not include it in the propensity score estimation described below.

\subsection{Sample size}

Most studies of treatment effects on firms use a large number of controls or untreated firms relative to the number of treated firms. This is often facilitated by the availability of government censuses of firms, which provide easy access to accounting data on all firms in a country. The reason for using a large number of untreated firms is that this increases the chances of finding one or several untreated firms that are very similar to a treated firm, thus facilitating the estimation of the treatment effect on the treated "twin". Our study has, by the standards of these studies, a modest number of untreated firms, as Table 2 shows, so the question of sample size needs to be addressed.

The power of any matching test depends on two factors, the existence of good untreated "twins" or controls for the treated firms and sample size. A large sample of untreated firms increases the likelihood that we can find one or more untreated firms that are very similar, if not identical, to each of the treated firms. However, the innate similarity between the firms in the treated and untreated sample also has to be considered. If all firms in the economy are very similar to each other, then the probability of finding a match between a treated and untreated firm can still be high even if the sample of untreated firms is small. This is point is most evident when matching techniques are used in psychology or medicine rather than in economics. Researchers in those disciplines sometimes use identical twins in studies of treatment effects. ${ }^{15}$ Note that in such

\footnotetext{
${ }^{11}$ For an assisted firm, the baseline year is the year before the year in which assistance is received. So "age" is the number of years the firm was in existence prior to the year in which it received assistance, and employment growth is then measured for employment for year $t$ (the year in which assistance was received), year $t+1$, the year after assistance was received, etc. So if we measure the effect of assistance for years $t, t+1, t+2$ and $t+3$, then we have to have at least three and at most 5 years of employment data for each firm treated in year $t$ and for the firms that are used as (potential) controls for this firm. For nonassisted firms used as controls in a given year between 1996 and 2006, the age is also measured for the year before the year in which the treated firms that are matched to the untreated firms received their assistance, and the employment growth rates are calculated for exactly the same years as those of the treated firms. Matching on a year by year basis controls for time-varying unobserved variables that may also influence employment growth.

${ }^{12}$ The default group is agriculture and the processing of agricultural products. This "deficit" of SMEs in manufacturing is characteristic of transition economies (Bartelsman et al., 2004).

${ }^{13}$ This may seem a surprisingly high proportion of firms with such a high level of exports, but it may accurately reflect Macedonia's relatively small domestic market, geography, and export structure. Many of the firms in our sample that export a large share of their production are firms engaged in agricultural processing. The south-eastern part of Macedonia, centered on the city of Gevgelia, enjoys a Mediterranean climate and engages in the growing of fruits and vegetables, especially in greenhouses, which permits a very long growing season. This part of Macedonia also borders Greece and is quite close to Thessaloniki, which is major population center in the region. Thus, agricultural production from this part of Macedonia is "processed" (which for agriculture may mean such simple activities as sorting, washing and packing) by small firms who then sell this produce directly in markets in adjacent Greece or to Greek wholesalers and retailers, especially to those in Thessaloniki where prices and incomes are higher than in Macedonia. A second group of small firms that engage in intensive export activity is to be found in the city of Tetovo, which is a center for textile and shoe manufacture. Most of the firms in Tetovo engage in what is called "lohnarbeit", the production of shoes and clothing on order for foreign department stores and retail chains. The foreigner supplies the material and designs, and the Macedonian firm then produces the required quantity of finished product and exports it. As this is a long-established business in Tetovo, even SMEs have the foreign contacts and skills necessary to participate in this form of subcontracting, which implies that the majority of their output is exported.

${ }^{14}$ The two largest firms in the sample received USAID assistance. If we drop these two firms from our sample, then the ratio of employment in assisted firms to employment in unassisted firms drops to about 2-1.

${ }^{15}$ See van Belle et al. (2004) for example.
} 
cases, the number of treated and untreated subjects is equal, but the matching of two twins with the same genetic and social characteristics ensures that each treated subject has a very close if not identical match. ${ }^{16}$ The more general implication then is that the adequacy of the number of controls available for achieving "good" matches is an empirical issue that depends on the similarly of the treated and untreated subjects in terms of the relevant covariates, a point made by Gauderman (2002) in a related context.

We note that our sample of firms is drawn from a small middle-income economy of about 2 million people that produces a relatively limited assortment of goods and services, and the firms interviewed were located in Macedonia's few major cities. Moreover, because this is a transition economy, these firms all came into existence at about the same time, after 1990 but before 2007, and thus they have very similar histories. As a result, the firms in our sample should be rather more homogenous than a sample of firms drawn from larger, more advanced and more economically diverse countries such as the UK or Germany, and the likelihood of finding comparable firms in our smaller control sample is consequently higher. We acknowledge that the studies we cite do use a larger sample of firms, but this larger number is often the result of researchers having access to extensive firm-level data from government surveys or censuses rather than being based on any objective statistical basis. Thus it is not clear that these studies establish a valid lower limit on sample size.

Further support for the belief that our sample of untreated firms yields sufficient matches for the treated firms comes from the fact that the two matching methods, caliper and kernel, that we use yield asymptotically identical results as the size of the control sample increases. Since in our case the two methods yield relatively similar treatment estimates, this can be taken as a sign that our control group size is sufficiently large given the degree of firm homogeneity in our sample. Finally, as part of our robustness tests, we examine whether changes in the value of the caliper change the number of acceptable matches, and, as reported below, we find that the number of matches between treated and untreated firms does not change with the value of the caliper, suggesting that the matches we do have are close ones and that the treated firms that do not have good counterparts among the untreated firms are well identified and excluded from the calculation of the treatment effect.

\section{Methodology}

To evaluate the employment generation impact of USAID programs we use a treatment effects methodology because we wish to account for the possibility of selectivity bias in USAID programs and to better distinguish the counterfactual of how employment in assisted firms would have grown in the absence of their participation in USAID programs. Selectivity bias may arise from two sources. First, USAID and its contractors may have chosen more productive and better-managed firms to participate in assistance programs, and these characteristics thus account for some or all of the seemingly better postassistance performance of these firms. The other source of bias is self-selection, whereby firms with better technology, better educated and more able managers, and better growth prospects would select themselves into the program. Thus, some of the post-participation increase in employment in those firms could, as well, be due to these characteristics rather than to the effectiveness of the assistance program. ${ }^{17}$ We use propensity score matching to minimize the effect of such biases on our results. ${ }^{18}$

There are three steps to our methodology, (i) the estimation of the propensity score and, subsequently, (ii) the matching of the treated firms and controls with the same estimated propensity score, and finally (iii) calculating the effect of treatment on employment change for each value of the estimated propensity score and averaging them to obtain ATT.

\subsection{Estimating the propensity score}

The first step is to estimate a logit model to determine the propensity score. For assisted firms, data in the year before assistance is used while for non-assisted firms, all observations are used. ${ }^{19}$ An issue in this step is what variables to include in the logit estimation. No algorithm exists for this choice, but one should choose variables that influence the firm's participation in the program and the program's effect on the firm. ${ }^{20}$ Economic theory and the nature of the data set can also guide this process. Most studies of firm responses to assistance use the firm's age and size, often measured by employment, as explanatory variables. Larger and more established firms may be better positioned to benefit from assistance and they may also be able to spare the time and resources needed for participation in assistance programs. In the case of Macedonia,

\footnotetext{
16 Ashenfelter and Krueger (1994) is a rare example of the use of identical twins for matching purposes in economics.

17 Chemin (2008) uses a matching methodology similar to that used in this paper to demonstrate that accounting for such biases significantly reduces the estimated effects of microfinance programs in Bangladesh.

18 See Caliendo and Kopeinig (2008) for a description of propensity score matching.

19 The difference between this and the usual propensity score estimation is that our data a firm can participate at any time. Therefore for non-participants all observations have to be used.

20 There is disagreement in the literature over the inclusion of variables when specifying the propensity scoring equation. Shadish et al. (2002, pp. 162-163) suggest that as many valid variables as possible (including interaction terms) should be included even if they are not statistically significant. Of the studies we have reviewed, only Almus (2001) appears to take this advice seriously by employing a battery of non-linear and interaction terms; other studies we cite appear to opt for a more parsimonious specification. Such parsimony also has clear support in the literature. For example, Caliendo and Kopeinig (2008, pp.38-39) warn against "overparametrized" propensity scoring models, and suggest a specification strategy that involves starting with a few basic variables such as age and some regional dummies and then iteratively adding other variables, which are retained only if they prove statistically significant "at conventional levels".
} 
much of the technical assistance offered was provided on an "on demand" basis. During the period under review, USAID let a variety of contracts to providers of assistance in Macedonia. Aid to firms included the establishment of business centers that helped firms with financial management, planning, product development and marketing. Other programs were shorter term in nature, and their names, such as the Entrepreneurial Management and Executive Development Program, the Macedonia Competitiveness Activity and the Strategic Technical Assistance for Results with Training (START), suggest that they often provided training through seminars and other short-term interventions. Thus, much of the participation in these technical assistance programs was driven by the decision of Macedonian managers to participate rather than on the basis of selections for participation by program organizers.

Consequently, we use the survey information on Macedonian managers' perceptions of the barriers to their firms' growth in our specification. If USAID seminars could provide information or training that Macedonian managers perceived as helpful in stimulating the growth of their firms, they would be more likely to attend, and if the information was useful and relevant, their firms would subsequently experience above average growth. The use of such "subjective" data as managers' opinions, as opposed to "objective" quantitative data on firms' characteristics, makes this study somewhat unique. Many studies use (often government-provided) accounting data on firms to calculate the propensity scores because these are the only data available, not because there is evidence that they are better than "subjective" data in predicting program participation. Thus, a potential strength of this study is that our surveys do provide subjective data on managers' perceptions of barriers to their firm's growth. If managers subjectively feel that their firm is held back by lack of management skills, they are more likely to participate in aid programs that develop such skills; managers who find it difficult to find suitable workers may participate in seminars that teach them about new technology that may substitute for such workers (e.g., information technology as a substitute for accountants), etc. If such subjective data were less useful in predicting program participation than are accounting data, our propensity scoring estimates would be less likely to satisfy the balancing tests, and the "subjective" variables' coefficients would not be statistically significant.

\subsection{Matching assisted and unassisted firms}

In the second stage, because it is unlikely that we can find two firms with exactly the same propensity score, we consider two commonly used matching methods, nearest- neighbor matching with caliper and kernel matching. ${ }^{21}$ The nearest-neighbor method matches each treated unit to its nearest neighbor with or without replacement. In the case of nearestneighbor matching with replacement, if the nearest control unit has already been used, it can be used again. This increases the average quality of the matches, but it can lead to lower variance for the estimated ATT. The use of a caliper reduces the risk of bad matches if the closest neighbor is far away by imposing a tolerance level on the maximum propensity score distance, the caliper. A small caliper will impose the common support condition. Imposing this condition will decrease the number of observations as those treated-untreated firms pairs that do not satisfy this condition are not used to estimate the treatment effect. We impose this condition and do not use replacement in our implementation of the methodology. In kernel matching, every treated unit is matched with a weighted average of all control units with weights that are inversely proportional to the distance between their scores and that of the treated unit. A small bandwidth for the kernel will lead to the imposition of a common support. We use the default bandwidth of 0.05 . In general, kernel matching is preferred to the caliper because the former uses more information from the data. However, for small samples, caliper matching may be more appropriate because it puts no weight on outlier non-treated firms, which may become a problem for kernel matching if there are many outliers in a small sample of untreated firms.

In the matching process, we match each firm that received USAID assistance to firms in the same pretreatment year as in Arnold and Javorcik (2009) and Todo (2008). ${ }^{22}$ This is crucial for our data set because firms are born within the sample period and USAID assistance occurs at different dates. Heckman et al. (1997) argue that geographic mismatches should be avoided in the context of job market evaluation programs. For our sample this amounts to avoiding period mismatches. With this approach, we insulate our ATT measures from time effects and endogeneity issues caused by having been selected for treatment in different years.

With either matching method we ensure that the balancing property is satisfied. In other words, the treated and control groups have the same characteristics after the matching process. We use four balancing tests as in Sianesi (2004). The first is sample $t$-tests that compare the covariates means of the treated and control groups before and after matching. Given that our matching is by period, the subsamples for the $t$-tests are from observations from corresponding periods. The second is a Hotelling $T$-squared test that tests the joint equality of means between the two groups for all covariates. In addition, we perform a pseudo $R$-squared test and a likelihood ratio (LR) test. These two tests evaluate the explanatory power of the covariates after matching using probit or logit estimation as before the matching. A successful matching should lead to low pseudo $R$-squared, and the estimated coefficients of the probit should be close to zero.

\footnotetext{
21 Another alternative is so-called synthetic matching as described by Abadie et al. (2010). This technique, however, requires the data on all firms treated in a given year to be averaged into a single observation. Such consolidation of observations destroys the information provided by individual firm data, and thus we do not use it in this paper.

22 To implement the methodology we modified the procedure used by Arnold and Javorcik (2009), which itself is a modification of psmatch2 of Leuven and Sianesi (2010).
} 


\section{Results}

\subsection{Propensity score estimation}

Table 4 shows the logit estimation results for the propensity score. Larger firms are more likely to participate than are small firms as the coefficient for total employment is positive and significant. The coefficients for log age is negative, but for log age squared it is positive, and both coefficients are significant. Thus older and more established firms are more likely to participate in assistance programs than are newly formed ones. The sector in which firms operate does not seem to affect the participation decision. Firms with at least one worker with a university education are more likely to participate in assistance programs. This may indicate that these firms are aware that external assistance in the form of training will boost their productivity and lead to expansion or that their greater technical expertise may have made them more attractive to those selecting firms for technical assistance programs. Firms that face greater competition from the black market underparticipate, perhaps because they are in sectors where business skills and technical expertise are not important sources of competitive strength, thus allowing small unregistered firms and black marketers to thrive. The difficulty of obtaining business premises does not affect the likelihood of participation significantly. Firms with internal cash flow constraints are more likely to participate. Such a lack of internal financing may lead firms to participate in technical assistance programs that help them with financial planning and management as well as in credit assistance programs to obtain external loans. On the other hand, firms reporting a lack of access to external finance as an important barrier did not participate more frequently in USAID programs. Firms that had difficulty in obtaining workers with the appropriate skills were more likely to participate, but those who found it hard to find skilled managers tended not to participate in assistance programs. The pseudo $R$-squared of the estimation is 0.175 .

These explanatory variables and the regression results, especially in terms of the effect of firm size and age and of managerial skills on the likelihood that a firm will participate in a program of technical or financial assistance, are quite similar to the those used by Almus (2001) for Germany, Gabe and Kraybill (2002) for the US and Roper and Hewitt-Dundas (2001) for Northern Ireland and the Republic of Ireland.

After computing the propensity scores from the logit estimation above, we used them to match firms by year either using caliper or kernel matching. This step should ensure that the treatment and new control group have similar characteristics. The balancing tests discussed earlier show that the matching is successful. In Table 5, we test that each variable has the same mean in the treatment and control groups. The $t$-tests are conducted before and after matching. We clearly see that before matching the treatment group and control group had very different characteristics. But after matching we cannot reject the hypothesis that the means are equal between the two groups. Also, the Hotelling T-test indicates that we cannot reject that the means are jointly equal between the two groups. The third test is the pseudo $R$-squared. From Table 5 , we see that, while

Table 4

Propensity score estimation.

\begin{tabular}{|c|c|c|}
\hline Treated $=1$ & Coefficient & Std. err. \\
\hline \multicolumn{3}{|l|}{ Continuous variables } \\
\hline Total employment & $0.461^{* * *}$ & 0.122 \\
\hline Log age & $-0.738^{*}$ & 0.459 \\
\hline Log age squared & $0.227^{*}$ & 0.126 \\
\hline \multicolumn{3}{|l|}{ Dichotomous variables } \\
\hline Sector $=$ industry & -0.875 & 0.803 \\
\hline At least one employee has university degree & $1.045^{* * *}$ & 0.391 \\
\hline \multicolumn{3}{|l|}{ Perceived barriers to growth ${ }^{\mathrm{a}}$} \\
\hline Competition from black market firms & $-0.635^{* * *}$ & 0.198 \\
\hline Access to a business premises & 0.231 & 0.234 \\
\hline Access to external finance & -0.236 & 0.192 \\
\hline Availability of internal finance & $0.800^{* * * *}$ & 0.201 \\
\hline Availability of inputs & $0.420^{*}$ & 0.250 \\
\hline Availability of labor & $0.343^{*}$ & 0.191 \\
\hline Legal disputes & $-0.242^{*}$ & 0.142 \\
\hline Availability of managers with appropriate skills & $-0.229^{*}$ & 0.121 \\
\hline No of observations & 822 & \\
\hline $\mathrm{Chi}^{2}$ & 73.29 & \\
\hline$P$ value & 0.000 & \\
\hline Pseudo $R$-squared & 0.175 & \\
\hline
\end{tabular}

Notes: The table reports logit estimations. The standard errors are computed using bootstrapping. The model includes an intercept term that is not reported.

* Statistical significance at the $10 \%$ level.

** Statistical significance at the $5 \%$ level.

**** Statistical significance at the $1 \%$ level.

a For definitions of these variables and their coding, see Table 1. 
Table 5

Balancing tests.

\begin{tabular}{|c|c|c|c|c|c|}
\hline \multirow[t]{2}{*}{ Variable } & \multirow[t]{2}{*}{ Sample } & \multicolumn{2}{|l|}{ Mean } & \multirow{2}{*}{$\begin{array}{l}t \text {-test } \\
t\end{array}$} & \multirow[t]{2}{*}{$p>t$} \\
\hline & & Treated & Control & & \\
\hline \multirow[t]{2}{*}{ Log(total employment before assistance) } & Unmatched & 2.278 & 1.501 & 5.03 & 0 \\
\hline & Matched & 1.987 & 1.936 & 0.18 & 0.856 \\
\hline \multirow[t]{2}{*}{ Log(age) } & Unmatched & 1.833 & 1.870 & -0.32 & 0.747 \\
\hline & Matched & 1.764 & 2.031 & -1.28 & 0.205 \\
\hline \multirow[t]{2}{*}{$\log (\text { age })^{2}$} & Unmatched & 4.304 & 4.180 & 0.3 & 0.767 \\
\hline & Matched & 3.996 & 5.267 & -1.68 & 0.097 \\
\hline \multirow[t]{4}{*}{ At least 1 employee has univ. degree sector = industry } & Unmatched & 0.034 & 0.062 & -0.84 & 0.402 \\
\hline & Matched & 0.021 & 0.043 & -0.58 & 0.562 \\
\hline & Unmatched & 0.776 & 0.560 & 3.22 & 0.001 \\
\hline & Matched & 0.745 & 0.702 & 0.46 & 0.649 \\
\hline \multicolumn{6}{|l|}{ Barriers to growth ${ }^{\mathrm{a}}$} \\
\hline \multirow[t]{2}{*}{ Competition from black market firms } & Unmatched & 1.207 & 1.584 & -2.89 & 0.004 \\
\hline & Matched & 1.298 & 1.298 & 0 & 1 \\
\hline \multirow[t]{2}{*}{ Access to business premises } & Unmatched & 0.552 & 0.551 & 0.01 & 0.995 \\
\hline & Matched & 0.574 & 0.702 & -0.76 & 0.45 \\
\hline \multirow[t]{2}{*}{ Access to external finance } & Unmatched & 1.207 & 1.130 & 0.61 & 0.544 \\
\hline & Matched & 1.149 & 1.170 & -0.09 & 0.925 \\
\hline \multirow[t]{2}{*}{ Access to internal finance } & Unmatched & 1.310 & 0.923 & 3.15 & 0.002 \\
\hline & Matched & 1.043 & 1.021 & 0.12 & 0.903 \\
\hline \multirow[t]{2}{*}{ Availability of inputs } & Unmatched & 0.690 & 0.640 & 0.52 & 0.603 \\
\hline & Matched & 0.702 & 0.702 & 0 & 1 \\
\hline \multirow[t]{2}{*}{ Availability of labor } & Unmatched & 0.966 & 0.736 & 1.94 & 0.053 \\
\hline & Matched & 0.745 & 0.809 & -0.35 & 0.724 \\
\hline \multirow[t]{2}{*}{ Legal disputes } & Unmatched & 0.879 & 1.124 & -1.15 & 0.251 \\
\hline & Matched & 0.894 & 0.894 & 0 & 1 \\
\hline \multirow[t]{2}{*}{ Availability of managers with appropriate skills } & Unmatched & 1.155 & 1.559 & -1.3 & 0.193 \\
\hline & Matched & 1.085 & 1.340 & -0.81 & 0.419 \\
\hline Hotelling $t$-test & F-statistic & 6.55 & $p$-Value & 0.00 & \\
\hline \multirow[t]{2}{*}{ LR test $-\mathrm{Chi}^{2}$} & Unmatched & 72.7 & $p$-Value & 0.00 & \\
\hline & Matched & 6.37 & $p$-Value & 0.932 & \\
\hline \multirow[t]{2}{*}{ Pseudo $R^{2}$} & Unmatched & 0.175 & & & \\
\hline & Matched & 0.049 & & & \\
\hline
\end{tabular}

a For definitions of these variables and their coding, see Table 1.

the pseudo $R$-squared was high before matching, it decreased substantially afterward. The last test is the LR test. The hypothesis we test is that the variables in the logit estimation have no explanatory power after matching. The $p$-value of LR statistic shows that this cannot be rejected. The kernel matching also passes all balancing tests. ${ }^{23}$

\subsection{Estimates of treatment effects}

In view of the previous discussion of the findings regarding the relative effectiveness of USAID financial and technical assistance to firms in Romania, we first sought to test whether the treatment effects for the eight firms in our sample that received financial assistance differed from the treatment effects of the firms that received technical assistance. Unfortunately, the small sample of firms receiving financial assistance was further attenuated by the fact that most of the financial assistance was received toward the end of the sample period, so that we had three and two firms only for estimating the treatment effects for employment growth two and 3 years after assistance respectively. This small sample size led to large standard errors for the estimates of the treatment effects and we were thus not able to reject the hypothesis that the treatment effects for the two groups of firms were the same. Thus, in the results that follow, we estimate a single treatment effect for all assisted firms regardless of the type of assistance they received.

Tables 6 and 7 report the average treatment effect on all the treated firms' employment growth using caliper and kernel matching methods. For both methods we impose the assumption of common support. In the case of caliper matching, we do not obtain matches for some treated firms. The number of firms that have matches is shown in Table 6 , and it is invariant within caliper values ranging from 0.01 to 0.2 . This suggests that we are not matching treated firms whose propensity scores appear to be quite different from those of firms in the control group and also that the firms for which we do have matches are matched quite well. The standard deviations are computed using bootstrapping with 100 replications. $^{24}$

We report the results for both full-time and total (including part-time) employment. The tables show that USAID assistance had a positive effect on employment growth. The ATT is positive for all years after assistance. While the size of the

\footnotetext{
23 The balancing tests for the kernel are not reported but are available upon request.

24 The bootstrap is computed by strata as the samples should be chosen by year.
} 
Table 6

Treatment effect with caliper matching with caliper of 0.05 and full sample.

\begin{tabular}{|c|c|c|c|c|}
\hline & Assistance year & One year later & Two years later & Three years later \\
\hline Full-time employment & $\begin{array}{l}0.123 \\
(0.085)\end{array}$ & $\begin{array}{l}0.203^{*} \\
(0.115)\end{array}$ & $\begin{array}{l}0.293^{* *} \\
(0.134)\end{array}$ & $\begin{array}{l}0.333^{*} \\
(0.185)\end{array}$ \\
\hline Total employment & $\begin{array}{l}0.126 \\
(0.082)\end{array}$ & $\begin{array}{l}0.214^{*} \\
(0.116)\end{array}$ & $\begin{array}{l}0.347^{* *} \\
(0.152)\end{array}$ & $\begin{array}{l}0.402^{* *} \\
(0.182)\end{array}$ \\
\hline Number of treated firms & 58 & 58 & 47 & 34 \\
\hline Number of matches with caliper $=0.05$ & 47 & 47 & 39 & 29 \\
\hline
\end{tabular}

The table shows average treatment on the treated. The standard errors in parentheses are calculated using bootstrapping. Results using a caliper of 0.01 and 0.20 excluded the same number of treated firms.

* Statistical significance at the $10 \%$ level.

** Statistical significance at the 5\% level.

*** Statistical significance at the $1 \%$ level.

Table 7

Treatment effect with kernel matching and full sample.

\begin{tabular}{|c|c|c|c|c|}
\hline & Assistance year & One year later & Two years later & Three years later \\
\hline Full-time employment & $\begin{array}{l}0.051 \\
(0.066)\end{array}$ & $\begin{array}{l}0.165^{* * *} \\
(0.082)\end{array}$ & $\begin{array}{l}0.201^{* * *} \\
(0.010)\end{array}$ & $\begin{array}{l}0.257^{*} \\
(0.144)\end{array}$ \\
\hline Total employment & $\begin{array}{l}0.054 \\
(0.061)\end{array}$ & $\begin{array}{l}0.177^{* *} \\
(0.082)\end{array}$ & $\begin{array}{l}0.256^{* *} \\
(0.129)\end{array}$ & $\begin{array}{l}0.330^{* *} \\
(0.146)\end{array}$ \\
\hline No of observations & 608 & 605 & 510 & 417 \\
\hline
\end{tabular}

The table shows average treatment on the treated. The standard errors in parentheses are calculated using bootstrapping.

* Statistical significance at the $10 \%$ level.

** Statistical significance at the 5\% level.

*** Statistical significance at the $1 \%$ level.

coefficients differs by matching method, the estimates are statistically significant from 1 year after assistance onward for both methods. For the caliper matching, the ATT estimates are larger than those for kernel matching. Full-time employment growth differentials vary from $12.3 \%$ in the assistance year to $33.3 \% 3$ years later. The range for total employment is from $12.6 \%$ to $40.2 \%$. While the estimates are not statistically significant during the assistance year, they are for the subsequent years.

The ATT estimates from the kernel matching are somewhat lower than the caliper estimates. Both full-time and total employment growth differentials are less than half of the caliper estimates in the year of assistance but more similar for subsequent years. One year after assistance, the kernel estimate of the employment growth differential of treated firms over untreated firms is $16.5 \%$ for full-time employment and $17.7 \%$ for total employment. By the end of the third year after assistance, the growth differentials increase to $25.5 \%$ for full-time employment and $33 \%$ for total employment. For all estimates, the effect of assistance on total employment growth is greater than the effect on full-time employment growth, suggesting that assisted firms made greater use of part-time employees, a positive outcome because the greater availability of part-time employment benefits workers who do not want to work full-time and because part-time work is a valuable gateway to fulltime employment for young workers, who face serious barriers in finding work in Macedonia.

As mentioned in Section 3, six of the firms in our ample received both financial and technical assistance in the same year. To test whether there is a synergistic effect between the two kinds of assistance, we estimated the ATT for these six firms alone. Unfortunately, this sample of firms, like those that received financial assistance only or first, had very few observations for employment growth 2 and 3 years following assistance. However, the estimated treatment effect for employment growth in the year of assistance was significant at the $5 \%$ level and about twice the ATT estimate for the entire sample of firms for that year. Given the small sample on which these estimates are based, the conclusion that there are synergies between financial and technical assistance, although commonsensical, should be treated less as a conclusive finding and more as an avenue for further research.

\subsection{Robustness tests}

Before comparing our results to those of other studies, we report two tests of robustness. ${ }^{25}$ As mentioned in Section 3 , the average size of treated firms was larger than that of the control group because of the presence of some very large firms in the treated group. To test whether the presence of these large firms skewed our results, we eliminated all firms with more than 100 employees from our sample and repeated our propensity matching procedure using this reduced sample. Results for the caliper test are reported in Table 8 for a caliper of 0.05 and the results of kernel matching are reported in Table 9. The reported results

${ }^{25}$ We thank a referee for suggesting these tests. 
Table 8

Treatment effect with caliper matching with caliper of 0.05 for firms with 100 or fewer employees.

\begin{tabular}{|c|c|c|c|c|}
\hline & Assistance year & One year later & Two years later & Three years later \\
\hline Total employment & $\begin{array}{l}0.120 \\
(0.090)\end{array}$ & $\begin{array}{l}0.212^{*} \\
(0.124)\end{array}$ & $\begin{array}{l}0.356^{* *} \\
(0.156)\end{array}$ & $\begin{array}{l}0.384^{* *} \\
(0.212)\end{array}$ \\
\hline No of treated firms & 52 & 52 & 42 & 32 \\
\hline No of matches with caliper $=0.05$ & 38 & 38 & 31 & 23 \\
\hline
\end{tabular}

The table shows average treatment on the treated. The standard errors in parentheses are calculated using bootstrapping.

* Statistical significance at the $10 \%$ level.

** Statistical significance at the $5 \%$ level.

*** Statistical significance at the $1 \%$ level.

Table 9

Treatment effect with kernel matching for firms with 100 or fewer employees.

\begin{tabular}{|c|c|c|c|c|}
\hline & Assistance year & One year later & Two years later & Three years later \\
\hline Total employment & $\begin{array}{l}0.035 \\
(0.115)\end{array}$ & $\begin{array}{l}0.171^{*} \\
(0.095)\end{array}$ & $\begin{array}{l}0.251^{*} \\
(0.137)\end{array}$ & $\begin{array}{l}0.302^{* *} \\
(0.151)\end{array}$ \\
\hline No of treated firms & 52 & 52 & 42 & 32 \\
\hline No of observations & 805 & 714 & 616 & 524 \\
\hline
\end{tabular}

The table shows average treatment on the treated. The standard errors in parentheses are calculated using bootstrapping.

* Statistical significance at the $10 \%$ level.

** Statistical significance at the $5 \%$ level.

*** Statistical significance at the $1 \%$ level.

are little different from those reported for the full sample, suggesting that the presence of some very large firms that received assistance in our sample did not skew the results reported for the full sample.

Since the main thrust of USAID assistance to Macedonian firms took the form of programs designed to improve managers' business and technical skills, a natural question to ask is whether those firms that felt that the lack of such skills was a major barrier to their growth consequently benefited more from USAID programs that addressed these skill shortages. To test for this we separated the firms in our sample into two groups, those that reported that the lack of managers with appropriate skills was not a barrier to their growth, and firms that reported that the lack of such skills was a moderate or serious barrier to growth. We then repeated the propensity scoring procedure, and we report the results of the caliper matching process for the two groups of firms in Tables 10 and 11 and for the kernel matching process in Tables 12 and 13 . While the results should be treated with caution given the small number of treated firms in each category, the results of the two matching methods point to the same conclusion. Firms that reported that the lack of appropriate managerial skills was not a barrier to growth exhibited no significant increase in growth as the result of participation in USAID programs. Firms that did report that lack of managerial skills was a barrier to their growth, on the other hand, experienced a significant increase in growth after participating in USAID programs. This suggests that Macedonian mangers could identify if a lack of business and technical skills was a barrier to firm growth and that USAID programs were able to improve participants' business and technical skills in ways that had tangible effects on firm performance.

\subsection{Comparison to other results}

In Table 14 we compare our results to those of studies of the effectiveness of assistance programs for firms carried out in other countries. This comparison should be treated with some care, as each country's assistance program was quite different in the type of aid provided, in the type of firms targeted for assistance, and in the amount and duration of assistance pro-

Table 10

Treatment effect with caliper matching with caliper of 0.05 for treated firms which reported that unavailability of appropriate managerial skills is not a barrier to growth.

\begin{tabular}{|c|c|c|c|c|}
\hline & Assistance year & One year later & Two years later & Three years later \\
\hline Total employment & $\begin{array}{l}0.051 \\
(0.273)\end{array}$ & $\begin{array}{l}0.250 \\
(0.335)\end{array}$ & $\begin{array}{l}0.206 \\
(0.497)\end{array}$ & $\begin{array}{l}-0.332 \\
(0.404)\end{array}$ \\
\hline No of treated firms & 27 & 27 & 22 & 14 \\
\hline No of matches with caliper $=0.05$ & 9 & 9 & 8 & 5 \\
\hline
\end{tabular}

The table shows average treatment on the treated. The standard errors in parentheses are calculated using bootstrapping.

* Statistical significance at the $10 \%$ level.

** Statistical significance at the 5\% level.

*** Statistical significance at the $1 \%$ level. 
Table 11

Treatment effect with caliper matching with caliper of 0.05 for treated firms which reported that unavailability of appropriate managerial skills is a barrier to growth.

\begin{tabular}{|c|c|c|c|c|}
\hline & Assistance year & One year later & Two years later & Three years later \\
\hline Total employment & $\begin{array}{l}0.047 \\
(0.087)\end{array}$ & $\begin{array}{l}0.297^{*} \\
(0.189)\end{array}$ & $\begin{array}{l}0.466^{*} \\
(0.255)\end{array}$ & $\begin{array}{l}0.471^{* * *} \\
(0.199)\end{array}$ \\
\hline No of treated firms & 31 & 31 & 25 & 20 \\
\hline No of matches with caliper $=0.05$ & 21 & 21 & 18 & 14 \\
\hline
\end{tabular}

The table shows average treatment on the treated. The standard errors in parentheses are calculated using bootstrapping.

* Statistical significance at the $10 \%$ level.

** Statistical significance at the $5 \%$ level.

*** Statistical significance at the $1 \%$ level.

Table 12

Treatment effect with kernel matching for treated firms which reported that unavailability of appropriate managerial skills is not a barrier to growth.

\begin{tabular}{|c|c|c|c|c|}
\hline & Assistance year & One year later & Two years later & Three years later \\
\hline Total employment & $\begin{array}{l}0.056 \\
(0.128)\end{array}$ & $\begin{array}{l}0.151 \\
(0.176)\end{array}$ & $\begin{array}{l}0.258 \\
(0.224)\end{array}$ & $\begin{array}{l}0.284 \\
(0.559)\end{array}$ \\
\hline No of treated firms & 27 & 27 & 22 & 14 \\
\hline No of observations & 343 & 304 & 261 & 220 \\
\hline
\end{tabular}

The table shows average treatment on the treated. The standard errors in parentheses are calculated using bootstrapping

* Statistical significance at the $10 \%$ level.

** Statistical significance at the $5 \%$ level.

*** Statistical significance at the $1 \%$ level.

Table 13

Treatment effect with kernel matching for treated firms which reported that unavailability of appropriate managerial skills is a barrier to growth.

\begin{tabular}{|c|c|c|c|c|}
\hline & Assistance year & One year later & Two years later & Three years later \\
\hline Total employment & $\begin{array}{c}-0.019 \\
(0.067)\end{array}$ & $\begin{array}{l}0.248 \\
(0.171)\end{array}$ & $\begin{array}{l}0.308^{* *} \\
(0.163)\end{array}$ & $\begin{array}{l}0.311^{* * * *} \\
(0.119)\end{array}$ \\
\hline No of treated Firms & 31 & 31 & 25 & 20 \\
\hline No of observations & 479 & 426 & 369 & 314 \\
\hline
\end{tabular}

The table shows average treatment on the treated. The standard errors in parentheses are calculated using bootstrapping.

* Statistical significance at the $10 \%$ level.

** Statistical significance at the $5 \%$ level.

**** Statistical significance at the $1 \%$ level.

vided. Moreover, the studies also differ in terms of the methodology used to account for selection bias. Some of the studies use matching methods similar to those employed in this paper, but others use different methods, mainly panel estimations that use firm characteristics to account for selectivity bias. ${ }^{26}$ Nevertheless, we note that most of the studies, except Brown et al. (2005) and Almus (2001), find first year effects that are similar in magnitude to ours. Moreover, many of the studies also find that assistance has longer-lasting effects on employment growth that continue to lead to higher employment growth for a number of years after firms receive assistance. Despite differences in countries studied, program design, sample size and econometric methodology, our results fall within the range of estimates provided by other studies for both transition and market economies.

Because we lack information about both the number of Macedonian firms that received USAID assistance and the costs of individual assistance programs, we are not able to estimate these programs' cost effectiveness. In our search for names of firms that had received USAID assistance in Macedonia, we did identify 786 firms that had participated in a USAID assistance program for which we were able to identify at least three Macedonian participants. If these firms had the same average level of employment as the firms in our "assisted" sample, then, in the first year after assistance, between 5900 and 7400 additional jobs would have been created, and this number would have increased in subsequent years, as the results reported in Tables 6 and 7 indicate. Such increases, sustained for a number of years, should have a significant impact on the labor market in a country the size of Macedonia.

\footnotetext{
26 In this respect the study by the Ministry of Economic Development of New Zealand (2009) is instructive because its authors provide estimates from the same data using both panel and matching methods. The conclusions obtained by the two methods are quite similar. Thus estimates obtained by different estimation methods may be comparable.
} 
Table 14

Comparison of assistance effects.

\begin{tabular}{|c|c|c|c|c|}
\hline Study & Country & Type of assistance & $\begin{array}{l}\text { Estimation } \\
\text { method }^{\mathrm{a}}\end{array}$ & $\begin{array}{l}\text { Increase in employment growth relative to growth of } \\
\text { unassisted firms }\end{array}$ \\
\hline This study & Macedonia & $\begin{array}{l}\text { Technical and } \\
\text { Financial }\end{array}$ & Matching & $\begin{array}{l}17-21 \% \text { points higher in } 1 \text { st year, } 26-40 \text { points higher by } \\
\text { 3rd year }\end{array}$ \\
\hline Almus (2001) & Germany & Financial & Parametric & Seven percentage points higher -effect lasts 6 years \\
\hline Brown and Earle (2009) & Romania & Financial & Matching & $\begin{array}{l}\text { Twenty percentage points in } 1 \text { st year, by } 5 \text { th year grows to } \\
40\end{array}$ \\
\hline Brown et al. (2005) & Romania & $\begin{array}{l}\text { Technical and } \\
\text { Financial }^{\mathrm{b}}\end{array}$ & Panel & Four percentage points higher than average growth of $6 \%$ \\
\hline Min. of Dev. (2009) & New Zealand & $\begin{array}{l}\text { Technical and } \\
\text { Financial }\end{array}$ & $\begin{array}{l}\text { Matching and } \\
\text { Panel }\end{array}$ & (Value added): 4-18 percentage points higher in first year \\
\hline $\begin{array}{l}\text { Roper and Hewitt-Dundas } \\
\text { (2001) }\end{array}$ & $\begin{array}{l}\text { Ireland and } \mathrm{N} \text {. } \\
\text { Ireland }\end{array}$ & $\begin{array}{l}\text { Technical and } \\
\text { Financial }\end{array}$ & Panel & 10-20 percentage points higher over 3 years \\
\hline Wren and Storey (2002) & UK & Technical & Panel & $\begin{array}{l}\text { 10-20\% growth of employment after assistance - } \\
\text { depending on firm size }\end{array}$ \\
\hline
\end{tabular}

a Panel and parametric estimates use firm characteristics to control for selection bias.

b Only financial aid has a significant effect on employment.

\section{Conclusions}

One key lesson from these results is that USAID-assisted firms increase both full-time and part-time employment at a much faster rate than do firms that did not receive assistance. Also the assistance has a lasting impact on employment growth. Thus we conclude that USAID provision of assistance to Macedonian firms had a significant effect on their ability to expand employment. The effectiveness of technical assistance is particularly important from a policy perspective in that some types of technical assistance programs, such as seminars that provide managerial skills and technical updates to attendees, could be expanded at relatively low marginal costs.

Our ability to extend our results is limited by the nature of the data available to us, but we note some areas where additional research is warranted. Although many studies evaluate assistance programs on the basis of employment or sales growth as well as of survival rates, the integration of survival rate effects with job growth effects would be an important next step for two reasons. The first is that many SMEs fail soon after startup, and thus assistance that helps firms survive may have employment effects that are as important as the increase in employment in firms that receive assistance and survive. Several studies cited in Section 2 do measure the effect of assistance on firm survival, but with contradictory results. ${ }^{27}$

A second area that deserves further research is that of crowding-out effects. While researchers find positive effects of assistance on the performance of individual firms, such effects tend to be smaller or to disappear entirely at the sectoral or aggregate level. This may be evidence that the firms that receive assistance prosper at the expense of other firms in their sector. As a result, the net employment effect seen at the firm level is not replicated at the aggregate level because firm growth within a sector is something of a zero-sum game where gains in productivity, sales and employment in assisted firms come at the expense of unassisted competitors.

A final issue that is neglected in this paper and in a number of other studies of the effectiveness of assistance programs is that of the costs and benefits of such assistance. Generally, programs that show a positive effect on employment or on other performance indicators in treated firms are deemed successful regardless of the costs of delivering this assistance. This is partly due to the difficulty of measuring, or obtaining data on, the administrative and direct costs of assistance programs as well as of valuing the gains in employment or growth in treated firms in monetary terms. Some studies that do undertake such cost benefit analysis, such as Hart and Gudgin (1999) or Gabe and Kraybill (2002), find that creating jobs through assistance to SMEs is a costly process. On the other hand, Wren and Storey (2002) find the technical assistance programs they examine in the UK to have "remarkably strong impacts, which indicate that the scheme was highly cost-effective." Thus, refining the success criteria for assistance programs to firms in transition economies to go beyond estimates of higher job growth and higher survival rates to include cost benefit analysis more explicitly is also an important next step.

\section{Acknowledgments}

The research underlying this paper was supported by a Contract from the United States Agency for International Development (USAID) and the Higher Education for Development (HED) Office to The Melikian Center for Russian, Eurasian and East European Studies at Arizona State University. We are indebted to Stephen Batalden, Paul Burgess, Hugh Haworth and Glenn R. Rogers for comments and advice in formulating the work performed under this contract and to Kathleen EvansRomaine and Victor Agadjanian for developing and implementing the surveys on which the current paper is based. Earlier

\footnotetext{
${ }^{27}$ Wren and Storey (2002) show that incorporating survival rates into the calculation of assistance effects makes an appreciable difference in the number of jobs ultimately created by assistance programs.
} 
versions of this paper were presented at the AAASS Meetings in Philadelphia in 2008 and the ASSA Meetings in San Francisco in 2009, and we are grateful to John Earle, Mieke Muers, the late Katherine Terrell, Jean Tesche and participants in those sessions as well as to participants in a seminar presentation at USAID for comments. We also acknowledge the assistance and advice of Beata S. Javorcik in implementing the statistical procedures used in this paper. Finally, we thank the Journal's referees for helpful comments that did much to improve this paper. The findings and conclusions reported herein are the responsibility of the authors and do not necessarily reflect the views of HED, USAID or the United States Government.

\section{References}

Abadie, Alberto, Diamond, Alexis, Hainmueller, Jens, 2010. Synthetic control methods for comparative case studies of aggregate interventions: estimating the effect of California's tobacco control program. Journal of the American Statistical Association 105, 493-505.

Almus, Matthias, 2001. Evaluating the Impact of Public Start-up Assistance - Results from an Econometric Approach. ZEW Discussion Paper No. 01-23. Available at SSRN. <http://ssrn.com/abstract=331063> or doi:10.2139/ssrn.331063.

Arnold, Jens M., Javorcik, Beata S., 2009. Gifted kids or pushy parents? Foreign direct investment and plant productivity in Indonesia. Journal of International Economics 79, 42-53.

Ashenfelter, Orley, Krueger, Alan, 1994. Estimates of the economic return to schooling from a new sample of twins. American Economic Review 84, 11571173.

Bartelsman, Eric, Haltiwanger, John, Scarpetta, Stefano, 2004. Microeconomic Evidence of Creative Destruction in Industrial and Developing Countries. IZA Discussion Paper No. 1374.

van Belle, Gerald, Heagerty, Patrick J., Fisher, Lloyd D., Lumley, Thomas S., 2004. Biostatistics: A Methodology for the Health Sciences, second ed. WileyInterscience, Hoboken.

Brash, Rachel, Gallagher, Megan, 2008. A Performance Analysis of SBA's Loan and Investment Programs. The Urban Institute, Washington, DC.

Brown, J. David, Earle, John S., 2008. Creating productive jobs in East European transition economies: a synthesis of firm-level studies. National Institute Economic Review 204, 108-125.

Brown, J. David, Earle, John S., 2009. Microcredit, Employment, Sales, and Survival: An Empirical Evaluation Using a Panel Matching Estimator. Working Paper, COST Action IS0701, Comparative Analysis of Enterprise Data.

Brown, J. David, Earle, John S., Lup, Dana, 2005. What makes small firms grow? Finance, human capital, technical assistance, and the business environment in Romania. Economic Development and Cultural Change 54, 33-70.

Caliendo, Marco, Kopeinig, Sabine, 2008. Some practical guidance for the implementation of propensity score matching. Journal of Economic Surveys 22, $31-72$.

Chemin, Matthieu, 2008. The benefits and costs of microfinance: evidence from Bangladesh. Journal of Development Studies $44,463-484$.

Chrisman, James J., McMullan, W. Ed, 2004. Outsider assistance as a knowledge resource for new venture survival. Journal of Small Business Management 42, 229-244.

Commander, Simon, Svejnar, 2011. Business environment, exports, and economic growth. Review of Economics and Statistics, 93, $309-337$.

Gabe, Todd M., Kraybill, David S., 2002. The effectiveness of economic development incentives on employment growth of establishments. Journal of Regional Science 42, 703-730.

Gauderman, W. James, 2002. Sample size requirements for matched case-control studies of gene-environment interaction. Statistics in Medicine 21, 35-50.

Hart, Mark, Gudgin, Graham, 1999. Small firm growth and public policy in Northern Ireland: making the difference? Environment and Planning C: Government and Policy 17, 511-525.

Heckman, James J., Ichimura, Hidehiko, Todd, Petra E., 1997. Matching as an econometric evaluation estimator: evidence from evaluating a job training program. Review of Economic Studies 64, 605-654

Johnson, Simon, McMillan, John, Woodruff, Christopher, 2000. Entrepreneurs and the ordering of institutional reform. Economics of Transition 8, 1-36.

Lehmann, Hartmut, 2010. Macedonian Accession to the EU and the Labor Market: What Can be Learned from the New Member States? IZA Policy Paper No. 14 , Bonn.

Lerner, Josh, 1999. The government as venture capitalist: the long run impact of the SBIR program. Journal of Business $17,285-318$.

Leuven, Edwin, Sianesi, Barbara, 2010. PSMATCH2: Stata Module to Perform full Mahalanobis and Propensity Score Matching, Common Support Graphing, and Covariate Imbalance Testing. <http://ideas.repec.org/c/boc/bocode/s432001.html>.

Meriküll, Jaanika, 2010. The impact of innovation on employment: firm- and industry-level evidence from a catching-up economy. Eastern European Economics 48, 25-38.

Ministry of Economic Development of New Zealand, 2009. Evaluation of the Growth Services Range: Statistical Analysis Using Firm-Based Performance Data.

Pissarides, Francesca, Singer, Miroslav, Svejnar, Jan, 2003. Objectives and constraints of entrepreneurs: evidence from small and medium-sized enterprises in Russia and Bulgaria. Journal of Comparative Economics 31, 503-531.

Roper, Stephen, Hewitt-Dundas, Nola, 2001. Grant assistance and small firm development in Northern Ireland and the Republic of Ireland. Scottish Journal of Political Economy 48, 99-126.

Shadish, William R., Cook, Thomas D., Campbell, Donald T., 2002. Experimental and Quasi-Experimental Designs for Generalized Causal Inference. Houghton-Mifflin, Boston.

Sianesi, Barbara, 2004. An evaluation of the Swedish system of active labor market programs in the 1990s. The Review of Economics and Statistics 86, 133155 .

Svejnar, Jan, 2002a. Transition economies: performance and challenges. The Journal of Economic Perspectives 16, 3-28.

Svejnar, Jan, 2002b. Labor Market Flexibility in Central and East Europe. William Davidson Working Paper No. 496.

Todo, Yasuyuki, 2008. Impact of Aid-Funded Technical Assistance Programs: Firm Evidence from the Indonesian Foundry Industry, Discussion Papers 08024, Research Institute of Economy, Trade and Industry (RIETI).

Westhead, Paul, 1995. Survival and employment growth contrasts between types of owner-managed high-technology firms. Entrepreneurship Theory and Practice 28, 5-27.

World Bank, 2007. How Well do Small and Medium Enterprise Programs Work? Evaluating Mexico’s Small and Medium Enterprise Programs Using Panel Firm Data. Mexico Country Management Unit, Poverty Reduction and Economic Management Division, Latin America and Caribbean Region, World Bank.

Wren, Colin, Storey, David J., 2002. Evaluating the effect of soft business support upon small firm performance. Oxford Economic Papers 54, 334-365. 